\title{
CITY PLANNING IN GRAECO-ROMAN TIMES WITH EMPHASIS ON HEALTH FACILITIES
}

\author{
L Cilliers and F P Retief (University of the Free State, Bloemfontein)
}

In this overview of city planning in Graeco-Roman times, starting with Greek gridiron street planning and functional city zoning in the $9^{\text {th }}$ century $\mathrm{BC}$, emphasis is placed on those aspects related to urban health and recreational activities. Etruscan-Roman expertise in hydraulic engineering facilitated the availability of ample water supplies, e.g. for public baths and latrines, and for efficient drainage systems, which had been problematic in the earlier Greek era. The Pax Romana obviated the need for defensive city walls and also potentiated the establishment and maintenance of long distance water supplies. Before the xenodocheia of the Christian era the only hospitals were Roman military institutions (valetudinaria) and some latifundia for sick slaves on large farms. Doctors practiced from very basic consulting facilities (iatreia, later tabernae). Graeco-Roman concepts of "death pollution” restricted structural burial facilities to a minimum, and situated outside the city walls. Greek recreation revolved around athletic sports practiced in stadia, gymnasia and occasionally in urban agoras; dramas were performed in open air theatres. The Romans preferred horse races and blood-thirsty sports in huge amphitheatres in which gladiators fought each other to the death.

\section{Introduction}

In Graeco-Roman antiquity the city was synonymous with civilization, as opposed to barbarity and chaos. To the Greeks the polis was essentially a community of citizens with common religious and cultural traditions - its physical attributes were of secondary importance. Their Roman successors, however, considered impressive buildings and civic amenities the hallmark of urban life (Owens 1992:1-2). In this study the evolution of city development during this period is reviewed with emphasis on health facilities and recreational amenities.

\section{The evolution of city planning}

In early (post-Mycenaean) Greece the creation of new colonies and cities date from the $11^{\text {th }}$ century BC. By the $8^{\text {th }}$ century BC huts had been completely replaced by rectangular houses, and in Ionia in particular various cities were flourishing. Cities were founded as the administrative and defensive centres of new colonies, or by synoecism (the political amalgamation of existing communities, e.g. Rhodes and Megalopolis). Owens (1992:7-8) states that two major Greek contributions to city planning were the so-called gridiron rectangular system of street construction, and the zoning of cities into e.g. public, private, economic and sacred areas. Gridiron planning evolved in approximately the $9^{\text {th }}$ century BC and was clearly evident in the $8^{\text {th }}$ century city of Megara Hyblaea. The gridiron system is often erroneously called the "Hippodamian system" after a famous $5^{\text {th }}$ century BC town planner who utilized 
the method (Tomlinson 1996:711). There was as yet no real coordination of city planning, but the evolving cities had certain features in common:

Most cities originated around a defensive position (usually an acropolis on high ground, with a palace and later temple) surrounded by a strong wall which followed the contours of the site, had forts at regular intervals and strong gates opposite the main streets. Defense potential, adequate water supply and economic potential were the most important factors in deciding on a site (Barnish 1996:1571-4). The agora was an open space, which acted as the city's political, economic, social and religious centre. Initially the assembly met here, but later it met in a council house (bouleuterion) or theatre, on or near the agora. Gradually the agora became rectangular with connected colonnades and stoas around three sides, and a freestanding stoa complex along the fourth side. Commerce centered on the agora and market places elsewhere, e.g. at main gates. Shrines commonly arose in the agora, as well as occasional temples. Simple houses with limited amenities and no gardens, initially arranged along haphazard and narrow streets, later became better organized in the gridiron streets system where the areas between these streets became known as insulae. Paving of streets was exceptional and sanitation poor (Mumford 1973:19, 153).

From the $6^{\text {th }}$ century BC city development improved progressively. Cities on the Greek mainland (e.g. Athens) remained less well planned than in the colonies of e.g. Ionia, Southern Italy, even North Africa. City states typical of central and Southern Greece did not extend to the colonies. Gradually the cities' centre of control shifted from the acropolis (which often became a sacred area) to the agora. Miletus and Smyrna in Ionia, and Syracuse and Acragas in Sicily stood out as very well planned cities (Mumford 1973:147-160). Ionian urban planning was to a limited extent influenced by the neighbouring Hittite, even Assyrian and Babylonian cultures (Mumford 1973:223).

During the period known as Classical Greece $\left(5^{\text {th }}\right.$ and $4^{\text {th }}$ centuries BC) orderly city planning improved further, potentiated by experts like Hippodamus of Miletus, the first city planner whose name is known to us. He reputedly planned the cities of Piraeus, Theorioi and Miletus (after its destruction by the Persians) (Owens 1992:30, 51-61). While Greece was characterized by great cultural and scientific development, the average city dweller still experienced a very simple life, basic housing facilities, limited food and amenities, and recurrent warfare and destruction. While Athens in particular was the centre of the intellectual activity, characteristic of the $5^{\text {th }}$ century $\mathrm{BC}$, its town planning was quite primitive compared with cities in Ionia and the eastern colonies. There was much speculation concerning the ideal city. In outlining his concepts, Aristotle proposed that "for the sake of beauty" streets should not be planned absolutely rectangular, that defensive walls remained essential, that the agora's economic and political functions should be separated and that gymnasia should be brought from the suburbs to the city centre (Politics 1330b 1331b). Plato had earlier advocated the gradual removal of defensive city walls (he thought the housing and street planning should be designed as defensive structures); a virtual ring of sacred temples should surround the agora, supplemented by the law courts and houses of senior officials (Laws 778a-779b.). He also described a quite 
idyllic picture of safe gardens in the Ilissos valley outside the Athenian walls (Phaedrus 229b, 230b). The suburbs were often a bonus for the city, with many impressive public buildings, recreational facilities and farmlands, in addition to industries and cemeteries (Owens 1992:152). Pausanias contrasts the agoras of previous centuries with the agoras of new cities and their sophisticated commercial facilities, shrines, temples and public buildings open to all citizens except criminals and accused persons (Description of Greece vi.24.2). Streets were still rarely paved (covered with gravel, beaten earth, potsherds and seashells) but insulae (street blocks) had become square which allowed for two rows of houses, placed back to back, with direct access to the streets (Owens 1992:156-7).

The Hellenistic era ( $3^{\text {rd }}$ century $\mathrm{AD}$ onwards) built on the preceding developments but with more spectacular planning including monuments, colonnades, dramatic terraces, temples and other public structures placed in elevated settings. The gridiron street system was firmly established, streets were wider and included impressive main avenues. Commercial and public buildings were now encroaching on the agora. The new cities of Alexandria and Halicarnassus were good examples of the new era, where rich patrons and kings had begun to carry the costs of the monumental structures (Mumford 1973:227-230; Owens 9, 68-70, 153). At this stage the Roman era dawned and with it combined Graeco-Roman developmental planning.

Before the $8^{\text {th }}$ century BC, Etruria and much of central and northern Italy were inhabited by a late Iron Age people, the Villanovans, who lived in round wattle, wood and mud huts. During the $8^{\text {th }}$ age BC the Etruscans replaced the Villanovans and started building rectangular houses of stone and mud bricks. Their biggest city, Veii, was characteristic of the Etruscan culture and demonstrated quite haphazard planning with primitive or no streets, and scattered houses, temples and cemeteries. It was however; built with a virtually impregnable citadel and excellent water supply and drainage system. Through contact with Greeks in Southern Italy and the Po valley, Etruscan city planning showed gradual development, as represented in cities like Spina, Marzabotto and Bolgia. Cities like Pompeii and Capua show progressive evidence of Etruscan, Greek and ultimately Roman influence (Owens 1992:100-106, 113-120).

Early Roman planning show evidence of both Etruscan and Greek-Hellenistic influence. Military factors also affected city planning, and Roman wars of conquest soon necessitated the establishment of cities for veterans. Based on a strict gridiron system these usually rectangular cities like Augusta Praetoria and Verona were rigidly designed, largely based on the "blue print" developed in $4^{\text {th }}$ century cities like Alba Fucens and Norica. With very strong central administrations they usually had excellent civic amenities, water supply and drainage systems. Much attention was also paid to religious sanctuaries (Owens 1992:113-120). Rome, however, retained its early haphazard structure. Even after the sack of Rome by the Gauls in 390 BC, the citizens took pains to rebuild the massive defensive walls as rapidly as possible, but took no trouble to plan streets and residential areas according to newer concepts (Mumford 1973:239).

During the Roman Empire city planning evolved mainly from GreekHellenistic origins, but also with a strong military component, e.g. Thamugadi and 
Cuicul in North Africa ( $1^{\text {st }}$ century AD). In the provinces liked Gaul and Britain, new cities served as military strongholds but also played an important role in spreading Roman culture. Cities tended to be more compact and centralized than their Greek equivalents, to have more decoration and monumental structures, better water supplies and sewage systems, and from the time of Julius Caesar standard paving of streets. Improved building techniques and hydraulic engineering facilitated this development (Barnish 1996:1571-4). Thanks to the Pax Romana, defensive city walls were no longer needed and after the $1^{\text {st }}$ century AD cities required imperial permission to erect such walls (Mumford 1973:239). Streets of newer cities became wider, the square Hellenistic insulae tended to become oblong, main north-south streets became known as cardo and east-west streets as decumanus. The forum (replacing the Greek agora) was where main streets or avenues crossed, and housed an increasing number of temples, public buildings, colonnades and markets. It lost its air of openness. Particularly in the East the increasing size of recreational facilities like baths and amphitheatres, progressively necessitated the siting of these structures on the outskirts of cities. Cities vied with each other regarding general appearance and amenities, and within cities rich citizens and nobility vied for public support (for the next election) through public donations and the dedication of buildings or other structures (Owens 1992:110, 154-6).

But while newer cities gained from more efficient city planning, old cities like Ostia and Rome largely retained their disorganized civic characteristics. Imperial Rome grew to a size of approximately 13 square kilometers, eventually harbouring 1,2 million inhabitants in seriously overcrowded residential areas. The streets were always a jumble, even after urban reconstruction following the great fire of AD 64 in Nero's time. There were narrow tracts for pedestrians (itinera), wider streets for single carts (actus) or 2 carts abreast (viae), while the proper streets (vici) were close on 3m wide (allowing for projecting balconies) (Carcopino 2004:27-29, 55-58). Julius Caesar passed strict laws to control the constant filth in the streets, but with little lasting effect (Carcopino 2004:56-57). Merchandise flooded the sides of the streets until Domitian forbade the practice (Martial Epigrams vii.61). Wheeled traffic was not allowed in day time, resulting in very noisy nights when wagon transport took place (Juvenal Satires iii.236-259). At night there was also total darkness. Street lighting was extremely rare in Roman times - Ephesus and Antioch being exceptions (Carcopino 2004:58; Owens 1992:158). Between Rome's city centre (forum) and the city walls were 14 residential regions with 3429 insulae in the New City and 2965 insulae in the Old City, where the rich and poor lived together. Carcopino (2004:289) estimates that there was probably on average only one domus (home of a rich person) per 26 insulae. Villas tended to be on the outskirts of the city and in the suburbs beyond the walls. The vast majority of Roman citizens lived in multistoreyed apartment blocks (tenements) fitted into the insulae; each block containing identical rooms (cenacula) with bay windows onto the street or a central court yard. The ground floor usually housed either the owner of the building, a rich tenant or tabernae (artists' shops or eating places); overcrowding and filth increased the higher upwards one moved in the building (Carcopino 2004:53-55). Petronius complained about the lice (Satyricon ch. 98). By the $3^{\text {rd }}$ century BC three-storeyed apartment 
blocks were common, but because of increasing construction problems and the collapse of buildings, Augustus decreed a maximum height of $20 \mathrm{~m}$, and Trajan reduced it to $18 \mathrm{~m}$. But in time this was overstepped and the insula of Felicula became famous for its structures which were 5 to 6 storeys tall (Carcopino 2004:29-31). In these tenements sanitation was rudimentary; the single window per cenaculum responsible for air and light had no glass panes but was covered by skin, cloth or wooden shutters. Heating was by way of individual braziers (no fire places allowed) and the fire hazard was high. Water was available at ground floor level. Insulae had their own water carriers (aquarii), porters (ostiarii) and sweepers (zetarii) (Carcopino 2004:43-48). Pliny commented on the common occurrence of climbing plants and potted window flowers on insulae (Natural History xix.59).

Rome and other cities of the Empire became known for their elaborate recreational facilities and also sacred places. In Rome the Campus Martius, for instance, covering 200 ha, was a place reserved for the gods only, with temples, tombs, and areas for funeral pyres.

\section{Health facilities}

The health of an urban population is of course determined by many factors which will change with time. The availability of health-related facilities such as sanitation, waste disposal, water supply and burial arrangements in Graeco-Roman antiquity is reviewed. The interest Vitruvius (early $1^{\text {st }}$ century AD) showed in the potential impact of health matters (climatic conditions in particular) on the siting and planning of cities is quite striking, although his confidence in the value of haruspication (inspection of animal livers) could hardly have been productive (On architecture 1.4 and $6 ; 1.7 .1-2 ; 2.8$ ). Four centuries earlier Hippocrates had already warned about the health hazards associated with marshy places and diseases caused by exposure to certain winds and climatic change. He advised extensively on the influence of winds, climate and seasons on urban planning (Airs, waters, places cc.1-11).

\section{Water supply}

An adequate water supply was essential for the siting and planning of all cities, and in early post-Mycenaean Greek cities such as Old Smyrna (11 ${ }^{\text {th }}$ century BC) and Pergamum, wells, springs and even rivers served as sources of water. Natural supplies could be supplemented with private and public cisterns which collected the run-off from roofs and even streets. The re-planning of Old Smyrna $\left(7^{\text {th }}\right.$ century BC) involved the construction of a public spring house. Fountain houses and spring houses subsequently appeared in many Greek cities, both as a public amenity and an embellishment. The Greeks were not known for their hydraulic engineering, but where necessary water was indeed channeled from afar. However, the political instability of the Greek world bred a reluctance to rely on distant water sources which could be destroyed by the enemy. Mumford (1973:192-3) states that piped water supplies in cities before the $5^{\text {th }}$ century BC was indeed rare. Water was carried by hand. The aqueduct of Eupalinos on the island of Samos was of early Greek construction, and the Peisistratids brought water in terracotta pipes from the Ilissos 
stream to the agora of Athens. Before this, Athens' water supply had been limited, but Cimon also improved the supply to the agora and public places. By the $5^{\text {th }}$ century BC Acragas was supplied by way of an impressive underground aqueduct. Syracuse and Olynthos had terracotta pipelines which brought water from $17 \mathrm{~km}$ and $18 \mathrm{~km}$ away, respectively. Pergamum had perhaps the most impressive aqueduct system, subsequently perfected in Roman times, which deposited water under pressure in holding tanks above the city. Water was distributed to fountains and fountain houses where it was available to citizens and some public buildings, but very few private homes (Owens 1992:15-21, 72, 158-161). During Hellenistic times water supply to cities improved significantly. In Pergamum a law was passed which made the creation of private cisterns compulsory (Owens 1992:81-90, 158-9).

The Etruscan city of Veii was founded after the $7^{\text {th }}$ century BC in a completely haphazard way in a strong defensive position, but it showed evidence of remarkably effective hydraulic engineering. Cisterns were constructed which often tapped water via rock-cut channels from underground sources. An effective rock-cut water drainage system was also present. Similar constructions pertained at other Etruscan settlements (Owens 1992:98). The Romans subsequently adopted and improved the Etruscan hydraulic skills, giving it high priority in their city planning. Aqueducts became a common sight, often instrumental in revitalizing cities, and the Pax Romana decreased the hazards of enemy interference with long distance water channels. Rome's first aqueduct, the Aqua Appia was completed in 312 BC. Eventually 11 aqueducts supplied the city, the last completed in AD 226. Most of the ample water supply went to public baths, but also to public fountains, nymphaea, water basins and latrines constructed throughout the city. All apartment blocks in the insulae received water (at ground floor level), as well as some public buildings and a large percentage of rich homes (the latter carried the lowest priority). The extensive water supply system had high maintenance cost and was efficiently run as a public amenity at minimal if any profit (Tomlinson 1996:133). The aquarii were special water carriers, who distributed water from public water-points. Juvenal considered them the lowest of the slave population (Satires vi.332).

\section{Drainage, sewage and waste disposal}

Evidence shows that in general the early Greeks were lax on sewage and waste disposal. According to Mumford (1973: 168, 188-9) there was tolerance of filth in public places, virtually no sanitation, no public latrines and few latrines in private homes. There was indeed little shame in public urination, and no waste or dung removal, which resulted in considerable open putrefaction. However, with no panGraecian co-ordination of city planning, conditions differed greatly from city to city, and there is evidence that Miletus in Ionia had a significant drainage system as early as the $8^{\text {th }}$ century BC. There is also evidence that Delos had an impressive underground drainage system in pre-classical times and possibly even latrines in private houses draining into this sewer. From the $8^{\text {th }}$ century BC Smyrna had cobbled streets with underground drains which emptied into the sea. By Classical times cities like Acragas, Rhodos, Pergamum and Athens had drainage and sewage systems (Owens 1992:18-9, 33, 47). In Athens private owners were allowed to dig their own 
(covered) drains, but resultant damage to streets had to be repaired, and in due course an efficient drainage system was developed which drained streets and houses into a main channel west of the agora. Here, as in other cities, legislation dealt with illegal dumping and waste removal, but streets were often evil smelling. Inadequate or nonexistent sanitary facilities led to dumping on streets and public areas, even when statutory dumps were provided. Maintenance of streets in Athens was the responsibility of astunomoi, who had gangs of slaves at their disposal. In several cities property owners were held responsible for maintenance of streets and waste disposal. Public officials supervised this and imposed fines for non-compliance (Owens 1992:168-9).

As already mentioned, the Etruscans initiated effective drainage systems in order to protect their cities from regular flooding, as early as the $7^{\text {th }}$ century BC. The Romans emulated them. Construction of the enormous Cloaca Maxima which drained central Rome into the Tiber river and had an exit diameter of 5 meters, was commenced in the $6^{\text {th }}$ century BC. All Roman cities were supplied with drainage systems which removed excess water and human and other detritus (Carcopino 2004:48-9). With few exceptions Graeco-Roman city drains simply emptied their contents outside the city walls (Owens 1992:152). Homes of the rich usually had ground floor latrines which flushed into the city mains or local cess pits; in Ostia and Pompeii there is evidence of a few second floor latrines. The insulae had no latrines (Juvenal Satires iii.275-8 warned about the problems of walking under open windows at night!). Here human waste collected in commodes (sellae pertusae) was deposited into a vat under the staircase well, from where it was manually emptied into dungheaps. Urine was commonly collected in special jars and supplied to fullers who used it in their trade (Suetonius, Vespasian c.23). However, receptacles with excrement were commonly emptied onto streets. Large numbers of water-flushed public latrines (forica) were built for the poor. A minimal entrance fee was charged. The buildings were often prominently decorated with indoor statues, and marble seats were arranged in rectangular or semicircular fashion. These forica were public in every sense - there was no embarrassment in using them, and meetings were even arranged there. Excess water from the aqueducts was utilized to flush the city sewers (Carcopino 2004:48$52)$.

\section{Medical practice}

In Homeric times the Greeks believed that disease was caused and controlled by the gods, with mantic and religious influences playing an overriding role. Medicine was thus in the hands of a heterogeneous community of "healers", including priests, magic healers, druggists and rootcutters. During the $6^{\text {th }}$ century BC a group of philosopherphysicians laid the early basis of rational medicine which led to the Hippocratic contributions of the late $5^{\text {th }}$ and $4^{\text {th }}$ centuries BC, which abandoned religion, magic and superstition as causes of illness, thus founding empiric medicine (Longrigg 1998:28-9). Simultaneously, however, the cult of Asclepius introduced elaborately designed temples for healing through incubation sleep. These Asclepieia should be seen as hydropathical institutions rather than as hospitals in the modern sense of the word. They were however seldom placed in cities - like modern health spa's they 
were usually constructed in a scenic country site. The typical Hippocratic doctor, on the contrary, probably practiced from very basic facilities in the city - perhaps a consulting room (iatreion) which was also his living quarters. A limited number of salaried civic doctors existed from at least the $5^{\text {th }}$ century BC but we have no information about their facilities. Hospitals as we know them did not exist. Basic operations, e.g. "cutting for stone" (lithotomy) were performed in the consulting room or the patient's home (Cilliers \& Retief 2002:61-2). The so-called "medical schools" of Cos and Cnidos ( $5^{\text {th }}$ century BC) were not circumscribed building complexes as we know them today; in fact, tradition has it that Hippocrates taught under a plane tree. The "medical school" of Alexandria (late $4^{\text {th }}$ century BC) functioned in the city, but the common concept that it was associated with the famous Museion and/or library cannot be substantiated. Medical education at the time consisted of in-service training and was not really institution bound (Retief \& Cilliers 2005:3-6).

Roman general medicine represented a continuation of the Greek model, but was significantly influenced by military implications. The first true hospitals were military institutions (valetudinaria) erected at the war front. There is evidence that in time valetudinaria were also instituted for imperial staff and the upper class, and that there were "hospitals" for gladiators and slaves on large farms (latifundia). Doctors still practiced from small consulting rooms (tabernae), some of which were sited in public baths. The suggestion that some tabernae developed into small house-hospitals (nosocomia) is little more than speculation; well-to-do households did however have quarters for the sick. The early Christians soon became known for their selfless dedication to the relief of suffering. When Constantine ( $4^{\text {th }}$ century) granted religious freedom and fostered the Christian belief, shelters for paupers, pilgrims and church messengers in the Greek-speaking East gradually evolved into the earliest hospices, called xenodocheia. In an attempt to gain support for his pagan countermeasures,

Julian the Apostate promoted the creation of xenodocheia which then also spread to the western part of the Roman Empire. Christian monasticism resulted in the creation of so-called infirmaries attached to monasteries. Mainly the result of Christian benefaction during the $4^{\text {th }}$ and $5^{\text {th }}$ centuries, hospitals now appeared in many centres (Cilliers \& Retief 2002:62-3.).

\section{Burial and cemeteries}

A belief in pollution by the dead (cultural and religious rather than physical pollution) held sway throughout Greek antiquity. Contact with the dead was thus minimized and within the city walls there were no structures for the handling of the dead. Before the $8^{\text {th }}$ century BC citizens could still be buried inside city walls but not after this time. Solon's extensive legislation (early $6^{\text {th }}$ century BC) regarding burial covered the prothesis (preparation of the body in the house where he/she died), the ekphora (funeral procession, before daybreak), burial and/or cremation procedures, and rules of mourning as well as follow-up visits to the grave. This remained in effect up to Roman times. Originally graves were simple square holes, with a minimal grave mound, but during the $5^{\text {th }}$ century elaborate grave stones, stelai and other structures started appearing on graves, until severely curtailed by decrees of Demetrius of Phaleron in the $4^{\text {th }}$ century BC. Slaves, strangers and the indigent were afforded 
decent burials, but the bodies of criminals were tossed into the sea, stone quarries or special pits. Persons who committed suicide had their right hands chopped off before being buried. Cemeteries commonly arose alongside streets leaving the city gates (Cilliers \& Retief 2002:17-26).

Roman concepts of death pollution showed similarity with those of the Greeks, but hygienic considerations gradually played a bigger role than the religiouscultural components. The laws of the Twelve Tables (451-449 BC) laid down legal requirements for handling of the dead and corresponded closely with Solon's laws in Athens. Because of regular epidemics and the progressive growth of Rome as a city (approximately 750000 inhabitants in the $1^{\text {st }}$ century BC and more than a million in the $2^{\text {nd }}$ century $\mathrm{AD}$ ) proper management of the dead became a major issue. After the $5^{\text {th }}$ century BC burials and cremation within the city walls were allowed only in exceptional cases. Outside the Esquiline gate in the grove of Libitina a funeral industry developed, run by professional libitinarii and funerarii who managed the vital burial process. In due course two burial areas developed: the loca religiosa along the highways leading from the gates of Rome, where proper graves, often richly decorated and family concerns with a distinctly religious character, were located, and the local public outside the Esquiline gate which served as place of execution and the final resting place for indigents, criminals and unidentified bodies. Here cadavers were commonly left in open mass graves (puticuli) which were covered over from time to time. Augustus finally converted this area into gardens and it is uncertain how the bodies of criminals and the poor were subsequently handled. Mass cremation in public crematoria (ustrinae) could have partially solved the problem, but evidence is that burial gradually replaced cremation in popularity after the $7^{\text {th }}$ century. On the Campus Martius, also outside the city walls (pomerium), a number of emperors and other illustrious individuals were buried in a sacred area with many temples, shrines and monuments (Cilliers \& Retief 2002:27-39).

\section{Sport and gymnasia}

The Olympic games introduced in 776 BC (and abolished by Theodosius I in 393 AD) typified the Greek approach to sport, health and fitness. Early sports grounds were called gymnasia, usually constructed outside the city walls as a public facility for all citizens. Commonly placed in sacred groves beside streams, there were three such gymnasia outside Athens. They typically contained running tracks, jumping pits and areas for throwing the javelin and discus. Two of the Athenian gymnasia were big enough for riding lessons and cavalry exercises. Other amenities included dressing and washing rooms, dusting rooms for powdering before exercises, rooms for ball games and boxing and palaestrae (low buildings mainly used for wrestling training). They were commonly used by epheboi (postpubertal boys who as part of their military training were also given cultural education with lessons in philosophy and literature). In Athens gymnasia employed trainers (gymnastai, paidotribai) (Tomlinson 1996:659-660). Sporting events were also held inside city walls and in the agoras in particular (Mumford 1973:162-3). At Pergamum there were interconnected gymnasia situated on the high terraces as part of a complex of temples, 
shrines and fountain houses. In late Hellenistic times these gymnasia were gradually replaced by the Roman public baths (Delaine 1996:235-6).

The Greek concept of sport and athleticism was never really accepted by the Romans. The younger Pliny clearly disapproved of it (Letters Bk. iv.22). Sulla, Pompey and Julius Caesar attempted unsuccessfully to popularize Greek games. Subsequently Augustus introduced his four-yearly Actiaca games, but as was later the case with Nero's Neronia, it never caught on. In AD 86 Domitian built the Circus Agonalis (15 000 seats) for his Greek-styled four-yearly Agon Capitolinus events, and the Odeon for spiritual and cultural contests. These were reasonably successful for selected audiences and lasted into the $4^{\text {th }}$ century. For the Roman upper classes Greek games were associated with nudity, even immorality and never rivaled their enthusiasm for gladiatorial shows and horse races. However, Greek communities persisted with their own games, which flourished in Attica and parts of southern Italy - but never in Rome (Carcopino 2004:301-3).

\section{Public baths}

Public baths, referred to as thermae, was a Roman institution introduced during the $2^{\text {nd }}$ century BC (Carcopino 2004:313). Dependent on generous water supply, these baths were as much a social recreational facility as an hygienic one. Initially males and females were admitted separately and a minimal admission fee ( $1 / 4$ as $)$ was required by the owner-builders; children were allowed in free of charge. By 33 BC Rome had 170 such public baths and they were steadily increasing in number. That year Agrippa, the aedile who was in charge of Roman baths, generously proceeded to pay all bath fees, and also built a new bath which was free of charge. His bath set the new norm and also became an architectural model. In the $1^{\text {st }}$ century AD a succession of emperors (Nero, Titus and Trajan) built baths, ever growing in size. The baths of Caracalla (AD 222-235), 27 acres, was eclipsed by Diocletian's complex covering 32 acres; Constantine built the last such bath in the $4^{\text {th }}$ century. Ultimately Rome had in excess of 800 public baths (Carcopino 2004:313-5).

The baths, built by all significant communities throughout the Empire, had a common basic lay-out consisting of changing rooms, a sweating room (caldarium) heated by an under-floor hypocaust, and a cold (unheated) room (frigidarium), both with plunging pools. More elaborate baths had dry heat rooms as well (laconica), intermediate temperature rooms (tepidaria), swimming pools, massage rooms, latrines, gardens and colonnades, service rooms and stoke-holes (praefurnia), lecture halls, libraries and museums, as well as exercising areas which largely corresponded to the Greek gymnasia. The baths played a central role in the daily lives of a large proportion of Romans. In Domitian's time men and women were bathing together, but in time this caused so much scandal that Hadrian again separated the sexes in AD 138 (Carcopino 2004:315). Public baths were constructed inside the city walls, as well as in the suburbs (Owens 1992:152). 


\section{Recreation and entertainment}

\section{Theatres}

The theatres in which Greek drama flourished in the $5^{\text {th }}$ and $4^{\text {th }}$ centuries BC were unroofed structures, usually situated in a hollow or against a hillside in order to accommodate the semicircular tiers of stone seats for the spectators. This component was called the auditorium (theatron), and it looked down on the circular or oval orchestra with its beaten ground floor for the performers. Primitive early examples are to be found at the Attic towns of Icaria and Thoricus, while Epidaurus had a splendid, near perfect theatre build in the $4^{\text {th }}$ century BC. Athens's original theatre was next to the agora, and the subsequent theatre of Dionysus against the Acropolis hill was built in the late $6^{\text {th }}$ century BC (Tomlinson 1996:1495). Most Greek cities had their theatres, with the oldest probably in Thoricus (south Attica), $10^{\text {th }}$ century BC (Owens 1992:21).

In the Roman world the oldest theatre was probably that in Pompeii, $5^{\text {th }}$ century BC. Theatres gradually ceased to be open-air structures and became roofed and enclosed in buildings. The seating was no longer against a hillside but incorporated into brick or stone walls (Tomlinson 1996:1495). Examples of these were the Theatre of Pompey in Rome (55 BC) with a semicircular diameter of 160 meters and seating for 27000 spectators; the Theatre of Balbus (13 BC), with 7700 seats, and the Theatre of Marcellus (11 BC) with 14000 seats and a diameter of 150 meters. During the Republican era Greek-styled drama was still as popular as the circus races, but then it went into decline. The last significant Roman dramatists like Accius, Pacuvius, Plautus and Terence wrote in the $2^{\text {nd }}$ and early $1^{\text {st }}$ century BC. Although drama was still performed well into the Christian era, diverbia (dialogues), cantica (songs) and pantomimes became more popular (Carcopino 2004:274-5.). The brutal culture of the amphitheatre and its munera (games) also found its way into the plays which became lurid, even bloodthirsty. This eventually led to its demise. The Theatre of Marcellus closed in AD 235, but some theatre activity continued up to the $6^{\text {th }}$ century (Carcopino 2004:274-5.).

\section{Amphitheatres and circuses}

The satirist Juvenal remarked that the degenerate Roman citizens cared only for bread and circuses (Satires x.77-81). The emperors arranged for the regular distribution of free bread, and also paid for frequent public amusement in the theatres and amphitheatres. Public holidays featured frequently on the Roman calendars. At the end of the first century BC there were 59 holidays per year. At the time of Julius Caesar this had increased to 132. By AD 354 there were approximately 200 holidays per year, 175 of which were dedicated to games and races. Providing adequate facilities for these events was a major challenge for city planners, and Carcopino (2004:251-4) speculates that in the heyday of the Empire the Roman citizens enjoyed more spectacles than any other community has, before or since.

The Circus, designed primarily for the races, was a long rectangular structure, rounded at one end into a semicircle. The Circus Maximus in Rome, oldest and 
largest, was build in the $2^{\text {nd }}$ century BC but enlarged by Caesar and Trajan to an ultimate size of $600 \times 250$ meters, seating 225000 (some said 385000 ) spectators. The Circus Flaminius (221 BC) was 400 x 260 meters, and the Circus Gai ( $1^{\text {st }}$ century AD) 180 x 90 meters (Mumford 1973:270-272). The smaller circus of Maxentius (AD 300) was outside the city walls on the Via Appia. Down the centre of each arena was the spina with turning posts at each end, dividing the area into two runs (Delaine 1996:332-3). Circuses were also found elsewhere in Italy and in the provinces. In Rome the initial 12 races per day (7 laps each) were later increased to 24 races per day. There were horse races and chariot races (up to 10 horses per chariot) and they competed under team colors - initially red and white, and later blue and green as well. The events were tremendously popular with the masses and were associated with heavy betting (Delaine 1996:332-3). However, persons like the younger Pliny (Letters ix.6.3) and Marcus Aurelius expressed their disdain with the races (Meditations c. 1.5).

Gladiatorial shows and spectacles with wild animals were held in amphitheatres, which were round or oval structures. These very popular performances, characterized by brutality and bloodshed, originated in Rome during the $2^{\text {nd }}$ century BC, and were initially held in temporary wooden amphitheatres, even in circuses. The first permanent amphitheatre in Rome was constructed in 29 BC, burnt down in $\mathrm{AD}$ 64, and was then splendidly reconstructed as the Flavian Amphitheatre or Colosseum (AD 80). It was oval, 188 x 156 meters in diameter and the seating area four storeys tall, accommodating 45000 spectators. Underground were extensive passages and rooms, and the central arena (3 500 meters) could be flooded for naval displays (naumachia). There was also the smaller amphitheatre Taurus, constructed by Augustus for land combats, and two Naumachia's (557 x 536 meters) specifically designed for naval combats. Amphitheatres were also built elsewhere in the Empire. The shows, called munera, were mainly financed by the emperors, and admission was free (Carcopino 2004:285-292). The first permanent amphitheatre of Roman construction was probably that at Pompeii, 80 BC (Delaine 1996:76).

The gladiators were recruited mainly from prisoners of war, convicts and men condemned to death by the courts. They were trained in special schools (ludi). Munera, like the races, were dawn to dusk events, in which pairs of gladiators would fight each other to the death. Shows often started with mimic fights (prolusio), preceding the real battle (hoplomachia); group combat and naval battles were also included. The munera involved wholesale massacres. Records from the $2^{\text {nd }}$ century mention two relatively minor munera where 202 and 350 gladiator pairs respectively took part, and a major munus, lasting 117 days in which 4741 gladiator pairs were involved. Trajan, Hadrian and Marcus Aurelius scaled down the bloodshed, and in the $5^{\text {th }}$ century the arrival of Christianity put an end to gladiatorial combats in the West. Wild animals often formed part of the shows, but gladiators never fought animals. This was left to bestiarii. Criminals who were convicted "ad bestias", were fed to the animals - and many early Christians died this way. When Titus inaugurated the Colosseum in AD 80, 5000 animals were killed on one day (Suetonius, Titus c. 7), and we have records of two munera in Trajan's time where 2256 and 443 animals 
were slaughtered. In 326 Constantine abolished "ad bestias" convictions, and ordained that large numbers of criminals be sent to work in mines, thus abolishing a main source of gladiators (Carcopino 2004:292-304).

\section{Public gardens and other facilities}

Mumford (1973:188-9) states that early Greek cities up to the $5^{\text {th }}$ century BC had very few gardens and parks. But by the $5^{\text {th }}$ century BC Athens had regular gardens planned and trees planted (Owens 1992:72, 152), and Plato presents an idyllic picture of the Athenian suburbs on the banks of the Ilissos river (Phaedrus 229b-230b). Suburbs had also acquired public amenities like libraries, bath houses, even museums (Owens 1992:152). The new city of Alexandria (331 BC) represented the Hellenistic era with carefully laid out gardens, public buildings, a museum and library (Strabo Geography 17.1.8-10). During the Roman Empire water supplies to cities received high priority, and in its heyday Rome had approximately 500 fountains, 30 public parks, 8 grassy commons and many gardens (Mumford 1973:273). City planning in the Roman provinces usually included public facilities like libraries, gardens or parks (Owens 1992:128, 136).

\section{Conclusion}

City planning formed an integral part of the evolution of the Graeco-Roman world over 12 centuries and more. The initial Greek contributions, like city zoning and gridiron street planning as early as the $9^{\text {th }}$ century BC, were fundamental, but subsequent Etruscan and Roman contributions were also important. The Etruscan contribution was restricted to hydraulic technology.

The changing Mediterranean world resulting from the Pax Romana greatly influenced city planning, for instance through the disappearance of city walls, the enabling of long distance water supplies and greater economic prosperity. Owens (1992:164) states that whereas the Romans tended to create artificially ordered townscapes, often with much ostentation, the Greeks retained a greater spontaneity in design which was characteristic of their whole way of life. Military realities greatly influenced Roman city planning, in the provinces in particular. They were quick to grasp new ideas of practical value and to develop new constructional techniques, so clearly demonstrated in their excellent hydraulic engineering feats and the construction of monumental buildings. Roman recreational concepts differed fundamentally from those of the Greeks. Whilst the latter focused on physical fitness programs in line with their Olympic Games ideals and the development of science, literature and drama, their Roman neighbours absorbed these academic achievements, but as far as sport and recreation were concerned, they focused on races in the massive circuses and gladiatorial shows in enormous amphitheatres. All this influenced city planning in the Greek and Roman spheres of influence, but in time a common developmental denominator did bring progressive uniformity within an encompassing Roman Empire. 


\section{BIBLIOGRAPHY}

Barnish, S J B 1996. Urbanism. In The Oxford Classical Dictionary. Third Edition, S. Hornblower \& A. Spawforth (eds). Oxford: University Press.

Carcopino, J 2004. Daily life in ancient Rome. London: Folio Society.

Cilliers, L \& Retief, F P 2002. The evolution of the hospital from antiquity to the end of the Middle Ages. Curationis 25.4:61-2.

Cilliers, L \& Retief, F P 2002. Begrafnisgebruike, die hiernamaals en doodsbesoedeling in antieke Griekeland. Akroterion 47:17-26.

Cilliers, L \& Retief, F P 2002. Begrafnisgebruike en doodsbesoedeling in antieke Rome: Prosedures en paradokse. Akroterion 47:27-39.

Delaine, J 1996. Amphitheatres. In The Oxford Classical Dictionary. Third Edition, S. Hornblower \& A. Spawforth (eds) 76. Oxford: University Press.

DeLaine, J 1996. Baths. In The Oxford Classical Dictionary. Third Edition, S. Hornblower \& A. Spawforth (eds) 235-6. Oxford: University Press.

Delaine, J 1996. Circus. In The Oxford Classical Dictionary. Third Edition, S. Hornblower \& A. Spawforth (eds) 332-3. Oxford: University Press.

Longrigg, J 1998. Greek Medicine. London: Duckworth Publishers.

Mumford, L 1973. The city in history. Middlesex, UK: Penguin Books.

Owens, E J 1992. The city in the Greek and Roman world. London \& New York: Routledge.

Retief, F P \& Cilliers, L 2005. Hippocrates: fact and fiction. In Health and healing, disease and death in the Graeco-Roman world. Acta Theologica Suppl. 7: 3-6.

Tomlinson, R A 1996. Aqueducts. In The Oxford Classical Dictionary. Third Edition, S. Hornblower \& A. Spawforth (eds) 133. Oxford: University Press.

Tomlinson, R A 1996. Gymnasium. In The Oxford Classical Dictionary. Third Edition, S. Hornblower \& A. Spawforth (eds) 659-660. Oxford: University Press,.

Tomlinson, R A 1996. Hippodamus. In The Oxford Classical Dictionary. Third Edition, S. Hornblower \& A. Spawforth (eds) 711. Oxford: University Press.

Tomlinson, R A 1996. Theatres. In The Oxford Classical Dictionary. Third Edition, S. Hornblower \& A. Spawforth (eds) 1495. Oxford: University Press. 